\title{
An Investigation of Financial Management Behaviors of Managers: Example of KOSGEB
}

\author{
Faruk DAYI iD a Yusuf ESMER iD b Bayram Ali KUKUS \\ a Kastamonu University, Faculty of Economics and Administrative Sciences, Kastamonu, Turkey. fdayi@kastamonu.edu.tr \\ b Bayburt University, Faculty of Applied Sciences, Bayburt, Turkey. yesmer@bayburt.edu.tr. (Corresponding Author) \\ c KOSGEB, Amasya, Turkey. bayram.kukus@kosgeb.gov.tr
}

\begin{tabular}{|c|c|}
\hline ARTICLE INFO & ABSTRACT \\
\hline $\begin{array}{l}\text { Keywords: } \\
\text { Behavioral Finance } \\
\text { Financial Management } \\
\text { Manager }\end{array}$ & $\begin{array}{l}\text { Purpose - The aim of this study is to analyze managers' financial management behaviors (cash } \\
\text { management, credit management, savings-investment and insurance). Financial management } \\
\text { behavior, therefore, plays a key role in the success of managers and organizations. Financial } \\
\text { management behavior refers to managers' individual and organizational decisions on and } \\
\text { practices in financial matters such as cash, loans, savings, investments and insurance. }\end{array}$ \\
\hline Financial Management Behavior & $\begin{array}{l}\text { Design/methodology/approach - Study sample consisted of } 85 \text { managers of KOSGEB (Small } \\
\text { and Medium Enterprises Development Organization, Turkey). Data were collected using survey } \\
\text { method. Data were analyzed using SPSS version 22. Frequency, percentage, mean, standard } \\
\text { deviation, reliability, factor analysis and ANOVA were used. }\end{array}$ \\
\hline $\begin{array}{l}\text { Revised } 12 \text { March } 2019 \\
\text { Accepted } 15 \text { March } 2019\end{array}$ & $\begin{array}{l}\text { Findings - Managers' financial management behaviors differ by experience, income and } \\
\text { education level. The higher their experience, income and education level, the higher their } \\
\text { insurance sensitivities. Managers have high tendency to credit management and cash } \\
\text { management behaviors, moderate tendency to savings-investment behaviors and medium to } \\
\text { low tendency to insurance behaviors. This result indicates that managers do not attach enough } \\
\text { importance to insurance, in other words, they are not cautious enough about insurance. }\end{array}$ \\
\hline & $\begin{array}{l}\text { Discussion - Participants' financial management behaviors differed by experience, income and } \\
\text { education level but not by gender, marital status, age and credit card use. This study is } \\
\text { important in the sense that it is one of the fewest studies addressing financial management } \\
\text { behavior. }\end{array}$ \\
\hline
\end{tabular}

\section{Introduction}

Managers are defined as people achieving goals through others, and various factors influence their decision making (Kocel, 1999: 15). Managers plan, organize, mediate, coordinate and supervise to achieve organizational goals (Genc, 2013: 22) and, to do that, they should have organizational, financial, supervisory and communication skills (Kucuk, 2014: 32). The personality traits of managers, therefore, become increasingly important. Managers' attitudes and behaviors resonate with other staff in an organization. Management is a matter of organization, and therefore, communication between organization members is of key importance. Decisions should be quick, and feedback should be timely. Having a highly motivated team is another factor affecting the success of an organization. The attitudes and behaviors of staff and managers affect organizational management. For example, people who do not like to take financial risks tend to behave cautiously and keep what they already have at hand, and therefore, make low-risk decisions. Managers who do not take risks might exhibit the same behavior and their financial management behaviors directly or indirectly affect organizational mission, vision, planning and operations. Managers' financial knowledge plays a significant role in basic financial management decisions such as preparing an operating budget, determining investment policies and making financial planning (Baris, 2016: 13). This means that managers' financial management behaviors have a significant impact on the welfare of organizations (Gonen and Ozmete, 2007: 57). For example, a manager who has difficulty paying his debts loses motivation when he 
thinks about how he will pay them (Lea et al., 1993: 85). It is, therefore, of significant importance to examine managers' financial management behaviors.

This study investigates managers' financial management behaviors in terms of the demographic variables: education, income and experience.

\section{Literature Review}

This section first delineates the concept of financial management behavior and then addresses the studies on the subject matter.

\subsection{Financial Management Behavior}

Behavior is defined as any observable or measurable movement of living things (Yilmazer and Eroglu, 2013: 10). It includes numerous psychological, biological and sociological factors as well, and therefore, it is a complex and difficult process to explain human behaviors (Ajzen, 1991: 179). Financial management behavior is a recent concept defined as the planning and operations of people and families regarding financial resources and demands (Heck, 1984: 13). In short, financial management behavior is the management of individuals' financial attitudes and actions. Financial decisions depend on morale, knowledge, attitudes, habits, experience and external factors. Not only financial knowledge but also income determines financial attitudes and behaviors (Parrotta and Johnson, 1998: 59). Such factors as human psychology, buying tendency and risk perception also affect financial decisions (Unal and Duger, 2015: 216). For example, someone who wants to take a loan first determines how much loan they will use and then compares interest rates and payment terms and decides about whether to take a loan or not depending on their income and expenses. Financial position is determined before financial planning (Dew and Xiao, 2011: 43). For example, having a written plan or budget to keep track of one's expenses and income can be considered a form of financial management behavior (Xiao et al., 2006: 109). Therefore, financial objectives result in financial behaviors.

One makes investments when one's income is greater than one's expenses, in other words, making investments depends on one's savings. It is, therefore, recommended that people be provided with basic financial education to improve their financial attitudes and behaviors. Borden et al. (2008: 25-26) report that American college students who receive basic financial education use credit cards more responsibly, resulting in a decrease in total credit card debt. This indicates that financial management behaviors affect buying decisions not only in the short term, but in the long term as well (Ibrahim and Alqaydi, 2013: 126). An increase in credit card spending results in a depleted reservoir of savings for future investments. According to Xiao et al. (2006: 108), people who wish to finance their consumption take out bank loans, work on parttime jobs to increase their income as they get older and exhibit behaviors that promote savings in order to provide for their family and to achieve higher prosperity in the long run. The reason behind this is that after their retirement, they want to have the same standards of living as before their retirement, and therefore, they make rational financial decisions that promote long-term economic gain.

Financial decisions depend on financial experience, financial thinking and financial knowledge (Nandagopal and Sathyapriya, 2016: 1288). Financial decisions, therefore, have an indirect effect on financial behaviors. According to Parrotta (1996: 4), marital status is another factor affecting financial management behaviors as well.

Economists state that people tend to save during earning periods and act rationally when managing money (Unal and Duger, 2015: 216). However, nowadays, people have difficulty managing money, turn to different financial instruments to meet their increasing needs and consume more than they save and bear high financial costs. Although financial decisions are generally individual decisions, habits and emotions sometimes play a role in business life. For example, Dew and Xiao (2011: 43) argue that positive financial management behavior is associated with physical and mental health, academic achievement and life satisfaction.

\subsection{Literature Review}

There are no studies, to our knowledge, that address managers' financial management behavior in Turkey and research abroad focuses not on financial management behavior but on financial behavior. 
Parrotta (1996) reported that financial management behavior is affected by financial knowledge and financial satisfaction but not by financial attitudes.

Grable et al. (2009) also reported that financial management behavior and important financial and investment decisions (interest rate and borrowing level) are affected by financial knowledge.

Theodos et al. (2014) reported that gender might have an effect on financial management behavior and that women have less financial knowledge than men, perhaps due to education level and income.

Mien and Thao (2015) conducted a study on Vietnamese youth and reported that financial knowledge and attitudes are positively related to financial management behaviors. They stated that financial attitudes and behaviors, financial knowledge, control horizons and financial management behaviors are interrelated concepts that affect financial management decisions in general.

Sekban and Atali (2017) examined the financial profiles of the managers of amateur sport clubs and reported that managers are not equipped enough to deal with financial problems that they face and that they should receive basic finance training to help them improve their financial behavior.

\section{Methodology}

This section describes the purpose, hypotheses, method and scales.

\subsection{Objectives and Hypotheses}

The aim of this study is to determine whether managers' financial management behaviors differ by education level, income and experience.

The hypotheses are as follows:

H1: Managers' financial management behaviors differ by management experience.

$\mathbf{H}_{2}$ : Managers' financial management behaviors differ by average monthly income.

$\mathbf{H}_{3}$ : Managers' financial management behaviors differ by education level.

\subsection{Method}

A quantitative research method was used in the study. Data were collected using a questionnaire. The study population consisted of all managers of KOSGEB operating in all cities of Turkey. The questionnaire was sent to 96 KOSGEB managers and 85 of them filled it out. Data were analyzed using SPSS version 22. Frequency, percentage, mean, standard deviation, reliability, factor analysis and ANOVA were used.

\subsection{Scales}

The survey consisted of two parts: (1) a 10-item questionnaire eliciting information on age, gender, income, experience, education level and credit card use and (2) the financial management behavior scale (FMBS) developed by Dew and Xiao (2011) and adapted to Turkish by Sekban and Atali (2017), who also added items to the scale based on literature review. The 15-item FMBS consists of 4 subscales (Cash Management, Credit Management, Savings and Investment and Insurance) and items are scored on a 5-point Likert scale (1: Never 2: Very Rarely 3: Occasionally, 4: Often, 5: Always). Table 1 shows the reliability coefficients of the FMBS.

Table 1. Reliability Coefficients of Subscales

\begin{tabular}{|c|c|c|c|c|c|}
\hline \multicolumn{2}{|l|}{ Scales } & \multicolumn{2}{|c|}{ Number of Items } & \multicolumn{2}{|c|}{ Cronbach's Alpha $(\alpha)$} \\
\hline \multirow{4}{*}{ FMBS } & Cash Management & 4 & \multirow{4}{*}{15} & 0.604 & \multirow{4}{*}{0.726} \\
\hline & Credit Management & 5 & & 0.634 & \\
\hline & Savings and Investment & 4 & & 0.612 & \\
\hline & Insurance & 2 & & 0.610 & \\
\hline
\end{tabular}

The Cronbach's alpha coefficient of the FMBS ranges from 0.60 to 0.80 (0.726), indicating that the scale is very reliable. The Cronbach's alpha coefficient of the subscales; cash management, credit management, savings and Investment and insurance are $0.604,0.634,0.612$ and 0.610 , respectively, indicating high reliability (Kayis, 2009: 403-405). 


\section{Results}

This section presents the factor analysis, demographic, descriptive statistical and hypothesis test results.

\subsection{Factor Analysis Results}

Factor analysis is a multivariate statistical analysis technique that converts a large number of interrelated variables into a smaller number of new variables. There are two types of factor analysis: exploratory and confirmatory. Exploratory factor analysis (EFA) is used to determine underlying factors that might explain observed variables. Confirmatory factor analysis (CFA) is used to test whether a predetermined model or hypothesis explains the relationship between observed variables (Buyukozturk, 2002: 472). Factor analysis gathers observed variables under a few factors with factor loadings (Cetin, 2007: 59), which are also referred to as correlation coefficients between observed variables and factors. In this study, an EFA was conducted to translate the statements describing participants' financial behaviors into factors. Table 2 and Table 3 show the EFA results.

Table 2. Percentage of Variance Explained by Subscales

\begin{tabular}{|l|l|l|l|l|}
\hline Subscales & Number of Items & $\begin{array}{l}\text { Cumulative Percentage of } \\
\text { Variance Explained (\%) }\end{array}$ & KMO & Sig. \\
\hline Cash Management & 4 & 47.644 & 0.563 & 0.000 \\
\hline $\begin{array}{l}\text { Credit } \\
\text { Management }\end{array}$ & 5 & 42.745 & 0.733 & 0.000 \\
\hline $\begin{array}{l}\text { Savings and } \\
\text { Investment }\end{array}$ & 4 & 49.573 & 0.573 & 0.000 \\
\hline Insurance & 2 & 71.953 & 0.500 & 0.000 \\
\hline
\end{tabular}

The subscale insurance accounted for $71.953 \%$ of the total variance explained, indicating that it plays a significant role in financial management behavior. The $\mathrm{KMO}$ value was greater than 0.5 , suggesting an adequate sample size for factor analysis. Table 3 shows the factor loadings of the subscales.

Table 3. Factor Loading Matrix

\begin{tabular}{|c|c|c|c|c|}
\hline \multirow[b]{2}{*}{ Items } & \multicolumn{4}{|c|}{ Factors-Factor Loadings } \\
\hline & $\begin{array}{l}\text { Cash } \\
\text { Management }\end{array}$ & $\begin{array}{l}\text { Credit } \\
\text { Management }\end{array}$ & $\begin{array}{l}\text { Savings and } \\
\text { Investment }\end{array}$ & Insurance \\
\hline $\begin{array}{l}\text { I compare prices before purchasing products and } \\
\text { services }\end{array}$ & 0.615 & & & \\
\hline I keep track of my monthly income and expenses. & 0.658 & & & \\
\hline I stick to my cash budget and spending plan. & 0.839 & & & \\
\hline I keep enough cash for emergencies. & 0.626 & & & \\
\hline I pay my bills and my due debts on time. & & 0.477 & & \\
\hline I pay off my credit card debt in full. & & 0.744 & & \\
\hline I max my credit cards. & & 0.641 & & \\
\hline Use cash as well as credit cards. & & 0.663 & & \\
\hline I pay the minimum payment on my credit card. & & 0.712 & & \\
\hline I always save money from every income I get. & & & 0.844 & \\
\hline $\begin{array}{l}\text { I invest my savings in gold or precious metals } \\
\text { funds. }\end{array}$ & & & 0.501 & \\
\hline $\begin{array}{l}\text { I invest my savings in interest-free banking } \\
\text { instruments. }\end{array}$ & & & 0.498 & \\
\hline $\begin{array}{l}\text { I save money for long-term goals such as cars, } \\
\text { education, home, land etc. }\end{array}$ & & & 0.879 & \\
\hline I always get comprehensive car insurance. & & & & 0.848 \\
\hline $\begin{array}{l}\text { I always have personal accident, life, earthquake, } \\
\text { fire insurance etc. }\end{array}$ & & & & 0.848 \\
\hline
\end{tabular}


F. Dayı - Y. Esmer - B.A. Kukus 11/1 (2019) 468-477

The EFA yielded four factors: (1) cash management, (2) credit management, (3 savings and investment, and (4) insurance, indicating that the scale has construct validity. The item "I stick to my cash budget and spending plan" accounted for $83.9 \%$ of the total variance of the factor cash management. The item "I pay off my credit card debt in full" accounted for $74.4 \%$ of the total variance of the factor credit management. The item "I always save money from every income I get" accounted for $84.4 \%$ of the total variance of the factor savings and investment. The items "I always save money from every income I get" and "I always have personal accident, life, earthquake, fire insurance etc." accounted for $84.8 \%$ of the total variance of the factor insurance.

\subsection{Demographic Results}

Table 4 presents the participants' demographic characteristics.

Table 4. Demographic Characteristics

\begin{tabular}{|c|c|c|c|}
\hline & & $\mathbf{N}$ & $\%$ \\
\hline \multirow[t]{3}{*}{ Gender } & Men & 77 & 90.6 \\
\hline & Women & 8 & 9.4 \\
\hline & Total & 85 & 100 \\
\hline \multirow[t]{7}{*}{ Age (Years) } & $26-30$ & 1 & 1.2 \\
\hline & $31-35$ & 15 & 17.6 \\
\hline & $36-40$ & 21 & 24.7 \\
\hline & $41-45$ & 26 & 30.6 \\
\hline & $46-50$ & 9 & 10.6 \\
\hline & $\geq 51$ & 13 & 15.3 \\
\hline & Total & 85 & 100 \\
\hline \multirow[t]{4}{*}{ Education Level } & $\mathrm{PhD}$ & 5 & 5.9 \\
\hline & Master's & 39 & 45.9 \\
\hline & Bachelor's & 41 & 48.2 \\
\hline & Total & 85 & 100 \\
\hline \multirow[t]{3}{*}{ Marital Status } & Single & 7 & 8.2 \\
\hline & Married & 78 & 91.8 \\
\hline & Total & 85 & 100 \\
\hline \multirow[t]{5}{*}{ Management Experience (Years) } & $1-5$ & 40 & 47.1 \\
\hline & 6-10 & 29 & 34.1 \\
\hline & $11-15$ & 6 & 7.1 \\
\hline & $\geq 16$ & 10 & 11.8 \\
\hline & Total & 85 & 100 \\
\hline \multirow[t]{4}{*}{ Average Monthly Income (Đ) } & $5000-7000$ & 11 & 12.9 \\
\hline & $7001-9000$ & 58 & 68.2 \\
\hline & 9001-11000 & 16 & 18.8 \\
\hline & Total & 85 & 100 \\
\hline \multirow[t]{3}{*}{ Credit Card Ownership } & Yes & 81 & 95.3 \\
\hline & No & 4 & 4.7 \\
\hline & Total & 85 & 100 \\
\hline \multirow[t]{6}{*}{ Number of Credit Cards } & 1 & 34 & 40.0 \\
\hline & 2 & 28 & 32.9 \\
\hline & 3 & 11 & 12.9 \\
\hline & 4 & 4 & 4.7 \\
\hline & $\geq 5$ & 4 & 4.7 \\
\hline & Total & 85 & 100 \\
\hline \multirow[t]{2}{*}{ Credit Card Limit (‡) } & $0-5000$ & 9 & 10.6 \\
\hline & $5001-10000$ & 14 & 16.5 \\
\hline
\end{tabular}


F. Dayı - Y. Esmer - B.A. Kukus 11/1 (2019) 468-477

\begin{tabular}{|l|l|c|c|}
\hline \multirow{4}{*}{ Frequency of Credit Card Use } & $10001-15000$ & 14 & 16.5 \\
\cline { 2 - 4 } & $15001-20000$ & 13 & 15.3 \\
\cline { 2 - 3 } & $\geq \mathbf{2 0 0 0 1}$ & $\mathbf{3 1}$ & $\mathbf{3 6 . 5}$ \\
\cline { 2 - 3 } & Total & 85 & 100 \\
\cline { 2 - 3 } & Every day & 25 & 29.4 \\
\cline { 2 - 3 } & Several times a week & $\mathbf{4 8}$ & $\mathbf{5 6 . 5}$ \\
\cline { 2 - 3 } & Several times a month & 6 & 7.1 \\
\cline { 2 - 3 } & Several times a year & 2 & 2.4 \\
\cline { 2 - 3 } & Total & 85 & 100 \\
\hline
\end{tabular}

$77(90.6 \%)$ participants were men and 78 (91.8\%) were married. This might suggest that married people are more likely to be employed as managers, perhaps on the assumption that they are more responsible than single people. 21 (24.7\%) participants were 36-40 while $26(30.6 \%)$ were $41-45$ years of age. $41(48.2 \%)$ participants had a bachelor's degree and $39(45.9 \%)$ had a master's degree. These demographics suggest that middle aged people with a bachelor's degree are more likely to be employed as managers. Managers with a bachelor's degree receive master's and $\mathrm{PhD}$ degrees later. $40(47.1 \%)$ participants had a $1-5$ years of managerial experience and $58(50 \%)$ had a monthly income of $€ 7001-9000.81(95.3 \%)$ participants had credit cards; $34(40 \%)$ had only one and $28(32.9 \%)$ had two. 31 (36.5\%) participants had credit cards with limits over $20.001 \mathrm{TL}$ and 48 (56.5\%) use their credit cards several times a week, indicating that they shop with credit cards and spend large sums of money.

\subsection{Descriptive Statistical Results}

This section presents the descriptive statistical results. Table 5 shows the frequency, mean and standard deviation values of the participants' responses to the questionnaire items.

Table 5. Descriptive Statistical Results

\begin{tabular}{|l|c|c|c|}
\hline ITEMS & N & Mean (X) & $\begin{array}{c}\text { Standard } \\
\text { Deviation }\end{array}$ \\
\hline CASH MANAGEMENT & $\mathbf{8 5}$ & $\mathbf{3 . 6 1 4}$ & $\mathbf{0 . 7 3 2 4}$ \\
\hline I compare prices before purchasing products and services & 85 & 4.153 & 0.8797 \\
\hline I keep track of my monthly income and expenses. & 85 & 3.200 & 1.4041 \\
\hline I stick to my cash budget and spending plan. & 85 & 3.553 & 0.9699 \\
\hline I keep enough cash for emergencies. & 85 & 3.553 & 1.0060 \\
\hline CREDIT MANAGEMENT & 77 & $\mathbf{4 . 4 4 9}$ & $\mathbf{0 . 5 9 5 7}$ \\
\hline I pay my bills and my due debts on time. & 85 & 4.729 & 0.6617 \\
\hline I pay off my credit card debt in full. & 81 & 4.679 & 0.6486 \\
\hline I max my credit cards. & 80 & 4.150 & 0.9427 \\
\hline Use cash as well as credit cards. & 79 & 4.430 & 0.8870 \\
\hline I pay the minimum payment on my credit card. & 79 & 4.165 & 1.3722 \\
\hline SAVINGS AND INVESTMENT & $\mathbf{8 5}$ & $\mathbf{3 . 4 2 9}$ & $\mathbf{1 . 2 9 8 2}$ \\
\hline I always save money from every income I get. & 85 & 3.235 & 0.9716 \\
\hline Save money for long-term goals such as cars, education, \\
home, land etc.
\end{tabular}

Participants had high credit management $(X=4.4)$ and cash management $(X=3.6)$ mean scores (4: close to often), a moderate savings and investment $(X=3.4)$ mean score (3: close to occasionally) and a low insurance $(X=2.77)$ mean score (3: close to but lower than occasionally "). The items with the highest scores in cash 
management, credit management, savings and investment and insurance were "I compare prices before purchasing products and services $(X=4.2)$," "I pay my bills and my due debts on time. $(X=4.7)$," "I save money for long-term goals such as cars, education, home, land etc. ( $X=3.4)$ "and "I always get comprehensive car insurance $(X=3.8)$," respectively. These results indicate that participants always compare prices when they shop, pay their bills and due debts on time, make investments and make sure that they have comprehensive car insurance.

\subsection{Hypothesis Results}

One-way ANOVA was used to determine whether participants' financial management behaviors (cash management, credit management, savings and investment and insurance) differed by management experience (Table 6).

Table 6. ANOVA Results for Management Experience

\begin{tabular}{|c|c|c|c|c|c|}
\hline & Years & $\mathbf{N}$ & Mean (X) & F & Sig. $(0.05)$ \\
\hline \multirow[t]{5}{*}{ Cash Management } & $1-5$ & 40 & 3.6063 & \multirow[t]{5}{*}{0.136} & \multirow[t]{5}{*}{0.938} \\
\hline & $6-10$ & 29 & 3.5776 & & \\
\hline & $11-15$ & 6 & 3.6250 & & \\
\hline & $\geq 16$ & 10 & 3.7500 & & \\
\hline & Total & 85 & 3.6147 & & \\
\hline \multirow[t]{5}{*}{ Credit Management } & $1-5$ & 38 & 4.3737 & \multirow[t]{5}{*}{1.297} & \multirow[t]{5}{*}{0.282} \\
\hline & $6-10$ & 25 & 4.4240 & & \\
\hline & $11-15$ & 5 & 4.5200 & & \\
\hline & $\geq 16$ & 9 & 4.8000 & & \\
\hline & Total & 77 & 4.4494 & & \\
\hline \multirow[t]{5}{*}{ Savings and Investment } & $1-5$ & 40 & 2.8938 & \multirow[t]{5}{*}{2.877} & \multirow[t]{5}{*}{0.041} \\
\hline & $6-10$ & 29 & 2.8190 & & \\
\hline & $11-15$ & 6 & 2.0000 & & \\
\hline & $\geq 16$ & 10 & 2.6250 & & \\
\hline & Total & 85 & 2.7735 & & \\
\hline \multirow[t]{5}{*}{ Insurance } & $1-5$ & 40 & 3.5250 & \multirow[t]{5}{*}{2.713} & \multirow[t]{5}{*}{0.050} \\
\hline & $6-10$ & 29 & 3.0172 & & \\
\hline & $11-15$ & 6 & 3.3333 & & \\
\hline & $\geq 16$ & 10 & 4.3000 & & \\
\hline & Total & 85 & 3.4294 & & \\
\hline
\end{tabular}

Participants' savings and investment and insurance subscale scores significantly differed by management experience $(\mathrm{p}<0.05)$, indicating that the more the management experience, the less the savings and investment tendency and higher the tendency to insurance. Thus, H1 was partially confirmed (Table 6).

One-way ANOVA was used to determine whether participants' financial management behaviors differed by average monthly income (Table 7). 
F. Dayı - Y. Esmer - B.A. Kukus 11/1 (2019) 468-477

Table 7. ANOVA Results for Average Monthly Income

\begin{tabular}{|c|c|c|c|c|c|}
\hline & $\mathbf{E}$ & $\mathbf{N}$ & Mean (X) & $\mathbf{F}$ & Sig. (0.05) \\
\hline \multirow[t]{4}{*}{ Cash Management } & $5000-7000$ & 11 & 3.3409 & \multirow[t]{4}{*}{0.924} & \multirow[t]{4}{*}{0.401} \\
\hline & $7001-9000$ & 58 & 3.6422 & & \\
\hline & $9001-11000$ & 16 & 3.7031 & & \\
\hline & Total & 85 & 3.6147 & & \\
\hline \multirow[t]{4}{*}{ Credit Management ( $(\mathbf{)})$} & $5000-7000$ & 9 & 4.2444 & \multirow[t]{4}{*}{0.648} & \multirow[t]{4}{*}{0.526} \\
\hline & $7001-9000$ & 53 & 4.4642 & & \\
\hline & $9001-11000$ & 15 & 4.5200 & & \\
\hline & Total & 77 & 4.4494 & & \\
\hline \multirow{4}{*}{$\begin{array}{l}\text { Savings and Investment } \\
\text { (ङ) }\end{array}$} & $5000-7000$ & 11 & 2.4091 & \multirow[t]{4}{*}{2.805} & \multirow[t]{4}{*}{0.066} \\
\hline & $7001-9000$ & 58 & 2.7586 & & \\
\hline & 9001-11000 & 16 & 3.0781 & & \\
\hline & Total & 85 & 2.7735 & & \\
\hline \multirow[t]{4}{*}{ Insurance (‡) } & $5000-7000$ & 11 & 2.6364 & \multirow[t]{4}{*}{3.029} & \multirow[t]{4}{*}{0.050} \\
\hline & $7001-9000$ & 58 & 3.4655 & & \\
\hline & $9001-11000$ & 16 & 3.8438 & & \\
\hline & Total & 85 & 3.4294 & & \\
\hline
\end{tabular}

Participants' insurance subscale scores significantly differed by average monthly income $(p<0.05)$, indicating that the more the average monthly income, the higher the tendency to insurance. Thus, $\mathrm{H} 2$ was partially confirmed (Table 6).

One-way ANOVA was used to determine whether participants' financial management behaviors differed by education level (Table 8).

Table 8. ANOVA Results for Education Level

\begin{tabular}{|c|c|c|c|c|c|}
\hline & Degree & $\mathbf{N}$ & Mean (X) & $\mathbf{F}$ & Sig. (0.05) \\
\hline \multirow[t]{4}{*}{ Cash Management } & Bachelor's & 41 & 3.5793 & \multirow[t]{4}{*}{0.942} & \multirow[t]{4}{*}{0.394} \\
\hline & Master's & 39 & 3.5962 & & \\
\hline & PhD & 5 & 4.0500 & & \\
\hline & Total & 85 & 3.6147 & & \\
\hline \multirow[t]{4}{*}{ Credit Management } & Bachelor's & 38 & 4.4632 & \multirow[t]{4}{*}{0.232} & \multirow[t]{4}{*}{0.793} \\
\hline & Master's & 35 & 4.4571 & & \\
\hline & $\mathrm{PhD}$ & 4 & 4.2500 & & \\
\hline & Total & 85 & 4.4494 & & \\
\hline \multirow[t]{4}{*}{ Savings and Investment } & Bachelor's & 41 & 2.6646 & \multirow[t]{4}{*}{0.854} & \multirow[t]{4}{*}{0.429} \\
\hline & Master's & 39 & 2.8782 & & \\
\hline & $\mathrm{PhD}$ & 5 & 2.8500 & & \\
\hline & Total & 85 & 2.7735 & & \\
\hline \multirow[t]{4}{*}{ Insurance } & Bachelor's & 41 & 3.0732 & \multirow[t]{4}{*}{3.919} & \multirow[t]{4}{*}{0.024} \\
\hline & Master's & 39 & 3.6795 & & \\
\hline & $\mathrm{PhD}$ & 5 & 4.4000 & & \\
\hline & Total & 85 & 3.4294 & & \\
\hline
\end{tabular}

Participants' insurance subscale scores significantly differed by education level $(\mathrm{p}<0.05)$, indicating that the higher the education level, the higher the tendency to insurance. Thus, H3 was partially confirmed (Table 6). 


\section{Conclusion and Recommendations}

Financial management starts in the family and everyone makes various financial decisions and puts them into practice throughout their lives. Financial management is essential for every family, and every family member contributes to the stability and development of family finances to achieve financial satisfaction (Yap, Komalasari \& Hadiansah, 2016, p. 140). People demonstrate the same financial management behavior as managers of enterprises and organizations. Therefore, their knowledge and experience are reflected in their organizational decisions. Individual financial management behaviors should be assessed to better understand their effect on enterprises and organizations.

Participants' financial management behaviors differed by experience, income and education level, suggesting that the higher the experience, income and education level, the higher the tendency to insurance. The better the basic financial knowledge, the more rational and reasonable financial behaviors the managers exhibit.

Participants' tendency to credit management and cash management is high. In cash management, participants compare prices before purchasing products and services and get the most at the least price. They have enough cash for their immediate needs and pay their bills and credit card debts on time and in full, thus, reducing default risk.

Participants' tendency to savings and investment behaviors is moderate, indicating that they do not care much about savings. They do not save much money from their income and they only save money after deducting their expenses from income. They are, however, aware that they should save money to make investments.

The concept of insurance is not well known in Turkey. Participants have comprehensive insurance because it is required by banks as a condition for financing the vehicle in the first place. They also get comprehensive insurance when the car is expensive. Although there are many insurance policies for accidents and other risks, this issue is not as widespread in Turkey as it is in some countries. The most popular insurance policies in Turkey are the Comprehensive Insurance for cars and the Turkish Catastrophe Insurance Pool (TCIP) for earthquake. Participants' tendency to insurance is slightly below the medium level, indicating that they do not pay enough attention to insurance-related financial management behaviors, that is, they do not act cautiously.

In conclusion, participants' financial management behaviors differed by experience, income and education level but not by gender, marital status, age and credit card use. This study is important in the sense that it is one of the fewest studies addressing financial management behavior. It is recommended that future studies use qualitative methods to gain a more in-depth understanding of the subject matter.

\section{References}

Ajzen, I. (1991). The Theory of Planned Behavior. Organizational Behavior and Human Decision Processes, 50(2), 179-211.

Baris, S. (2016). Finansal Okuryazarlik ve Butceleme Davranisi: Universite Ogrencileri Uzerine Bir Arastirma. TESAM Akademi Dergisi, 3(2), 13-38.

Borde, L. M., Lee, S.-A., Serido, J., \& Collins, D. (2008). Changing College Students' Financial Knowledge, Attitudes, and Behavior through Seminar Participation. Journal of Family and Economic Issues, 29(1), 23-40.

Buyukozturk, S. (2002). Faktor Analizi: Temel Kavramlar ve Olcek Gelistirmede Kullanimi. Kuram ve Uygulamada Egitim Yonetimi, (32), 470-483.

Cetin, A. C. (2007). Sirket Derecelendirilmesinde Faktor Analizi Kullanimi ve Sektorlere Yonelik Bir Uygulama. Suleyman Demirel Universitesi Iktisadi ve Idari Bilimler Fakultesi Dergisi, 12(3), 53-74.

Dew, J., \& Xiao, J. J. (2011). The Financial Management Behavior Scale: Development and Validation. Journal of Financial Counseling and Planing, 22(1), 43-59. 
F. Day1 - Y. Esmer - B.A. Kukus 11/1 (2019) 468-477

Genc, N. (2013). Meslek Yuksekokulları Icin Yonetim ve Organizasyon (Guncellenmis 3.Baski b.). Ankara: Seckin Yayincilik.

Gonen, E., \& Ozmete, E. (2007). Finansal Refah: Finansal Yonetim Surecinden Duyulan Tatmin, Finansal Davranislar ile Oz-Saygi Arasindaki Iliskinin Incelenmesi. Aile ve Toplum Egitim, Kultur ve Arastırma Dergisi, 3(11), 57-69.

Grable, J. E., Park, J.-Y., \& Joo, S.-H. (2009). Explaining Financial Management Behavior for Koreans Living in the United States. The Journal of Consumer Affairs, 43(1), 80-107.

Heck, R. K. (1984). The Determinants Of Financial Management Behaviors Among College Students: Implicatıons For Consumer Education. The Journal of Consumer Education, 2, 12-17.

Ibrahim , M. E., \& Alqaydi , F. R. (2013). Financial Literacy, Personal Financial Attitude, And Forms, of Personal Debt among Residents of the UAE. International Journal of Economics and Finance, 5(7), 126138. doi:10.5539/ijef.v5n7p126.

Kayis, A. (2009). Guvenilirlik Analizi (Reliability Analysis). In S. Kalayci, SPSS Uygulamali Cok Degiskenli Istatistik Teknikleri (4. b., pp. 403-419). Ankara: Asil Yayin Dagitim.

Kocel, T. (1999). Isletme Yoneticiligi, Yonetim ve Organizasyon, Organizasyonlarda Davranis, Klasik-ModernCagdas Yaklasimlar (7.Baski b.). Istanbul: Beta Basim Yayim Dagitim.

Kucuk, O. (2014). Girisimcilik ve Kucuk Isletme Yonetimi (Yedinci Baski). Ankara: Seckin Yayincilik .

Lea, S. E., Webley, P., \& Levine, R. M. (1993). The Economic Psychology of Consumer Debt. Journal of Economic Psychology, 14(1), 85-119.

Mien, N. T., \& Thao, T. P. (2015). Factors Affecting Personal Financial Management Behaviors: Evidence from Vietnam. Proceedings of the Second Asia-Pacific Conference on Global Business, Economics, Finance, (s. 1-16). Danang-Vietnam.

Nandagopal, R., \& Sathyapriya, M. (2016). A Study on Factors Influencing Personal Financing Decisions of Management Students in Coimbatore. Asian Journal of Research in Social Sciences and Humanities, 6(8), 1288-1304. doi: 10.5958/2249-7315.2016.00682.1

Parrotta, J. L., \& Johnson, P. J. (1998). The Impact of Financial Attitudes and Knowledge on Financial Management and Satisfaction of Recently Married Individuals. Financial Counseling and Planning, 9(2), 59-75.

Parrotta, J. M. (1996). The Impact of Financial Attitutes and Knowledge of Financial Management and Satisfaciton. Thesis of Master, The University of British Columbia, Canada.

Sekban, G., \& Atali, L. (2017). Amator Spor Kulubu Yoneticilerinin Finansal Profilleri. Uluslararasi Kulturel ve Sosyal Arastirmalar Dergisi (UKSAD), 3(2), 306-315.

Theodos, B., Kalish, E., McKernan, S.-M., \& Ratcliffe, C. (2014). Do Financial Knowledge, Behavior, and WellBeing Differ by Gender? Urban Institute. Retrieved on 13.09. 2017 from https://www.urban.org/sites/default/files/publication/22456/413077-Do-Financial-Knowledge-

Behavior-and-Well-Being-Differ-by-Gender-.PDF

Unal, S., \& Duger, Y. S. (2015). Akademik Personelin Finansal Gonenc Hali ve Finansal Davranis Egilimi Arasindaki Iliskiye Yonelik Ampirik Bir Arastirma. Ekonomik ve Sosyal Arastirmalar Dergisi, 11(1), 213-226.

Xiao, J. J., Sorhaindo, B., \& Garman, E. T. (2006). Financial Behaviours of Consumers in Credit Counselling. International Journal of Consumer Studies, 30(2), 108-121. doi:10.1111/j.1470-6431.2005.00455.x

Yap, R. J., Komalasari, F., \& Hadiansah, I. (2016). The Effect of Financial Literacy and Attitude on Financial Management Behavior and Satisfaction. International Journal of Administrative Science E Organization, 23(3), 140-146.

Yilmazer, A., \& Eroglu, C. (2013). Meslek Yuksekokullari Icin Davranis Bilimleri ve Orgutsel Davranis (Dorduncu Baski ). Ankara: Detay Yayincilik. 